\title{
Corporate growth, sustainability and business ethics in twenty-first century
}

\author{
Sanjay Kumar Singh ${ }^{1}$. Sanjaya S. Gaur ${ }^{2}$ \\ Published online: 30 April 2020 \\ (c) Springer Science+Business Media, LLC, part of Springer Nature 2020
}

The twenty-first century and that after COVID-19 requires corporate growth, but based upon sustainability and business ethics, to take the economic growth of the world back on the track. The contemporary business world is full of surprises and it is in this context that the corporate should practice a governance structure whose essence should be to balance the influence of stakeholders' pressure, culture, and corporate social responsibility (Gaur et al. 2019; Kowalczyk and Kucharska 2020). Different model of corporate governance-market oriented and network orientedare in practice across the globe but its essence has been to mitigate conflict of interests amongst the stakeholders (Bottenberg et al. 2017). The corporate governance helps ensures corporate accountability through the mechanisms of processes, customs, policies, laws \& institutions, and the likes. Moreover, the demands from the larger society has been that the company should not only aim to be profitable but it needs to demonstrate ethical corporate behaviors, environmental awareness, sound corporate governance, and the likes (e.g., Bhaumik et al. 2019; El-Kassar and Singh 2019; Patnaik et al. 2018). However, the discipline of Corporate Governance is not 'static' but 'organic' in character. In other words, to be competitive in the fast changing world, the firms need to continuously reinvent their corporate governance structure so that they effectively meet any new opportunities as thrown to them by the post-modern world economy. It is in this context that a need has been felt amongst the academics, practitioners, policy makers, social activists, etc. to revisit the challenges and opportunities confronted by the discipline of corporate governance and business ethics (e.g., Mitra and Gaur 2020; Mukherjee et al. 2019; Singh et al. 2020).

Sanjay Kumar Singh

sanjay.singh@adu.ac.ae

Sanjaya S. Gaur

sonjaya.gaur@nyu.edu

1 College of Business, Abu Dhabi University, Abu Dhabi, UAE

2 Department of Integrated Marketing, NYU School of Professional Studies, New York University, New York, NY, USA 
This special issue on "Corporate Growth, Sustainability and Business Ethics in 21st Century" in Journal of Management and Governance was well received and it received several paper submissions. However, only six papers, after several rounds of reviews and revisions, were found suitable and hope they will be liked by the readers.

The first paper titled "Corporate governance and performance of microfinance institutions: recent global evidences" suggests that microfinance institutions (MFIs), which are socially than commercially oriented, show stronger focus on social goals by having higher percentage of female borrowers and lower average loan size. It also examined the influence of ownership structure on MFIs' social performance.

The next paper is titled "role of individual's virtues in relationships between emotional responses to government's actions and their consequences". The key findings of this manuscript suggest how the individual differences influence negative emotions and resultant behaviors. This study throws several research questions for future scientific investigations in the field.

The 3rd paper titled "Ownership concentrations, board characteristics and firm performance among Shariah-compliant companies" throws light on how corporate governance mechanisms influence firm performance in Shariah-compliant firms. Furthermore, it also suggest that ownership concentration to positively influence the firm performance of Shariah-compliant companies.

The following paper is titled "Innovating for competitive advantage: managerial risk-taking ability, counterbalances management controls". The study advances literature in the field of strategic management through validation of dynamic capability theory in the context of emerging markets. From a methods perspective, this paper illuminates the use of multiple mediation procedure and provides direction for future researches in the field.

The penultimate paper is titled "The relationship between CSR and corporate governance moderated by performance and board of director's characteristics". The key findings of this study suggest that ethical practices plays mediating role on to the linkages between audit committee component of corporate governance and corporate social responsibility. It also offers direction for future research in the area of corporate social responsibility.

The last paper titled "Do firm specific characteristics and industry classification corroborate voluntary disclosure of financial ratios: an empirical investigation of S\&P CNX 500 companies" is in Indian context. The results of the study have been discussed in detail and it suggests for mandatory reporting of select ratios and standardization of the methods used in calculation of financial ratios. Furthermore, it suggests that voluntary disclosures results in reduction in information asymmetry amongst the investors and augments long-term business sustenance and also to strengthens governance norms.

We hope that these six papers in this special issue will provide fresh insights and resulting discourse on "Corporate Growth, Sustainability and Business Ethics in 21 st Century". 


\section{References}

Bhaumik, S., Driffield, N., Gaur, A., Mickiewicz, T., \& Vaaler, P. (2019). Corporate governance and MNE strategies in emerging economies. Journal of World Business, 54(4), 234-243.

Bottenberg, K., Tuschke, A., \& Flickinger, M. (2017). Corporate governance between shareholder and stakeholder orientation: Lessons from Germany. Journal of Management Inquiry, 26(2), 165-180.

El-Kassar, A. N., \& Singh, S. K. (2019). Green innovation and organizational performance: the influence of big data and the moderating role of management commitment and HR practices. Technological Forecasting and Social Change, 144, 483-498.

Gaur, A., Ghosh, K., \& Zheng, Q. (2019). Corporate social responsibility (CSR) in Asian firms: A strategic choice perspective of ethics and compliance management. Journal of Asia Business Studies, 13(4), 633-655.

Kowalczyk, R., \& Kucharska, W. (2020). Corporate social responsibility practices incomes and outcomes: Stakeholders' pressure, culture, employee commitment, corporate reputation, and brand performance. A Polish-German cross-country study. Corporate Social Responsibility and Environmental Management, 27(2), 595-615.

Mitra, A., \& Gaur, S. S. (2020). Does environmental concern drive Asian firms' governance? Journal of Asia Business Studies. https://doi.org/10.1108/JABS-06-2019-0189.

Mukherjee, D., Lahiri, S., Ash, S. R., \& Gaur, A. S. (2019). Search motives, local embeddedness, and knowledge outcomes in offshoring. Journal of Business Research, 103, 365-375.

Patnaik, S., Temouri, Y., Tuffour, J., Tarba, S., \& Singh, S. K. (2018). Corporate social responsibility and multinational enterprise identity: insights from a mining company's attempt to localise in Ghana. Social Identities, 24(5), 604-623.

Singh, S. K., Del Giudice, M., Chierici, R., \& Graziano, D. (2020). Green innovation and environmental performance: The role of green transformational leadership and green human resource management. Technological Forecasting and Social Change, 150, 119762. https://doi.org/10.1016/j.techf ore.2019.119762.

Publisher's Note Springer Nature remains neutral with regard to jurisdictional claims in published maps and institutional affiliations. 